\title{
EFEKTIVITAS TEPUNG DAUN SAMBILOTO (Andrographis paniculata nees) SEBAGAI ANTIBAKTERI TERHADAP PERFORMANS BROILER YANG TERINFEKSI Escherichia coli
}

\section{The Effectiveness of Sambiloto Leaf Flour (Andrographis paniculata nees) as an Antibacteria on Escherichia coli Infected Broiler Performance}

\author{
Rosa Tri Hertamawati, Niswatin Hasanah, Adline Putri Sabrina \\ Department of Animal Husbandry, Polytechnic State of Jember \\ Jalan Mastrip PO Box 164 Jember, Telp : 0331-333532, Fax : 0331-333531 \\ E-mail: niswatinhasanah122@gmail.com
}

\begin{abstract}
Rapid broiler development is one of the reason farmers' choice in raising broiler. The effect broiler become weak because of diseases even come from bacteria or viruses. One of the diseases which are leaded by bacteria which attack broiler oftenly is colibacillosis. The aim of this experiment was to examine the addition of sambiloto leaf meal on feed to the inhibition of bacterial development inside the body of infected Escherichia coli broiler toincrease broilers performance. This experiment used 100 day old chicks (DOC) of Cobb strain which were kept for five weeks. The experiment used completely randomized design with five treatments and four replications consisting of 5 broilers in each replication. The treatments were $P 0=$ control (healthy broiler), $P 1=P 0$ infected with Escherichia coli, $P 2=P 1+0,2 \%$ sambiloto leaf meal, $P 3=P 1+0,4 \%$ sambiloto leaf meal, $P 4=P 1+0,6 \%$ sambiloto leaf meal. The data were analyzed with analysis of variance. The variables observed were feed consumption, body weight gain, final body weight, feed conversion ratio, mortality, and total colony bacteria in broiler excreta. The result showed that sambiloto leaf meals $0.6 \%$ have a significant effect in decreasing bacteria.
\end{abstract}

Keywords: Antibacterial, Broilers, Eschericia coli, Performance, Sambiloto leaf meal

\section{PENDAHULUAN}

Usaha yang dilakukan peternak untuk meningkatkan produktivitas broiler adalah dengan penggunaan antibiotik karena kondisi broiler yang rentan terhadap penyakit baik yang berasal dari bakteri maupun virus. Penggunaan antibiotik juga mampu meningkatkan efisiensi ransum, sehingga dapat menguntungkan peternak (Mustaqim, 2006). Salah satu penyakit asal bakteri yang sering menyerang ternak broiler adalah kolibasilosis. Kolibasilosis merupakan penyakit yang berasal dari bakteri Escherichia coli (E. coli).

Bakteri E. coli biasanya tercemar melalui air minum. Meskipun dampaknya tidak terlalu berbahaya, tapi jika jumlah E. coli yang masuk dalam tubuh broiler besar, maka saluran pencernaannya akan terganggu sehingga bobot badannya tidak akan maksimal. Salah satu cara menghambat perkembangan E.coli adalah dengan pemberian antibiotik.
Sambiloto merupakan salah satu tanaman antibiotik alami serta merupakan salah satu tanaman bakterostatik pada Escherichia coli (E. coli). Pemberian tepung daun sambiloto pada pakan broiler menurut hasil penelitian terdahulu dapat menghambat perkembangan bakteri dan dapat meningkatkan performans broiler. Penelitian penggunaan sambiloto sudah dilakukan pada broiler. Pemberian tepung daun sambiloto pada broiler tidak berpengaruh terhadap bobot badan dan konversi ransum, tetapi berpengaruh menurunkan mortalitas broiler (Tipakorn, 2002). Penggunaan tepung ekstrak daun sambiloto dengan konsentrasi $20 \mathrm{mg} / \mathrm{ml}$ dapat menghambat pertumbuhan Aspergillus flavus isolat $\mathrm{BCC}$ (Balitvet Cultur Collection) dan isolate pakan. Menurut Mustaqim (2006) menyatakan bahwa pemberian sambiloto dengan dosis $800 \mathrm{mg} / \mathrm{kg}$ bobot badan, menunjukkan efek perlindungan terhadap organ hati itik dari kerusakan akibat aflatoxin. 
Tujuan penelitian ini adalah untuk mengkaji pemberian tepung daun sambiloto pada pakan terhadap penghambatan perkembangan bakteri dalam tubuh broiler yang terinfeksi $E$. coli sehingga meningkatkan performans broiler.

\section{MATERI DAN METODE}

\section{Pembuatan tepung daun sambiloto}

Proses pembuatan tepung daun sambiloto dilakukan dengan cara memisahkan daun sambiloto dari tangkai, dicuci bersih dan ditiriskan, kemudian dikeringkan/dijemur hingga kadar air mencapai 7\% kemudian digiling halus.

\section{Pembiakan E. coli}

Pembiakan E. coli dilakukan dengan cara biakan E. coli pada Nutrient Agar (NA), diremajakan 1--2 ose pada medium NA, kemudian diinkubasi selama 24 jam. Hasil inkubasi diambil 1-2 ose dan dimasukkan pada media Nutrient Broth (NB) $100 \mathrm{ml}$ kemudian diinkubasi kembali selama 24 jam, setelah itu dihitung jumlah bakteri (sel/ml).

Penelitian dilaksanakan menggunakan metode percobaan dengan Rancangan Acak Lengkap (RAL). Perlakuan yang diberikan adalah 3 kelompok broiler yang diinfeksi $E$. coli dan ditambah tepung daun sambiloto dengan level $0,2 \% ; 0,4 \%$; dan $0,6 \%$ (P2, P3, P4), satu kelompok kontrol/ayam sehat (P0), serta satu kelompok dengan perlakuan penginfeksian $E$. coli (P1). Setiap perlakuan diulang 4 kali, sehingga terdapat 20 unit percobaan, yang masing-masing terdiri dari 5 ekor broiler. Pemberian tepung daun sambiloto dilakukan pada umur 8--35 hari, dan penginfeksian E. coli dilakukan secara oral pada umur 14 hari sebanyak $1,42 \times 10^{10} \mathrm{cfu} / 0,5 \mathrm{ml} /$ ekor

Variabel yang diamati meliputi: konsumsi pakan, pertambahan bobot badan, bobot badan akhir, konversi pakan dan total bakteri umur 21 dan 28 hari. Pakan diberikan dengan menambahkan $10 \%$ dari standar kebutuhan broiler dengan kandungan protein $21 \%$ dan EM $3100 \mathrm{kkal} / \mathrm{kg}$ (BR1 Wonokoyo) dan air minum diberikan secara ad libitum.

\section{Perhitungan jumlah bakteri $\boldsymbol{E}$-coli}

Penghitungan Total Plate Count (TPC) bakteri dilakukan dengan cara menimbang sampel ekskreta 0,5 gram kemudian dimasukkan pada tabung reaksi yang telah diisi garam fisiologis $(\mathrm{NaCl} 0,85 \%) 9 \mathrm{ml} /$ tabung dan dikocok (vortex) hingga homogen, kemudian tiap tabung reaksi diambil $1 \mathrm{ml}$ dan dimasukkan pada tabung reaksi lainnya hingga tabung reaksi kedelapan (pengenceran $10^{-1}--10^{-8}$ ). Tiap tabung reaksi diambil $1 \mathrm{ml}$ dan ditaruh pada cawan petri dengan medium NA masing-masing $25 \mathrm{ml}$ kemudian diinkubasi pada suhu $30^{\circ} \mathrm{C}$ selama 24 jam. Hasil inkubasi dihitung jumlah koloni bakteri setiap pengenceran dengan rumus:

Jumlah sel bakteri $(\mathrm{CFU} / \mathrm{g})=\mathrm{Jml}$ koloni X Vol Sampel yang diinokulasi X (1/Pengenceran) / Berat sampel.

\section{Rancangan Penelitian}

Rancangan Penelitian yang akan digunakan dalam penelitian ini adalah Rancangan Acak Lengkap (Complete Rondomized Design). Untuk mengetahui adanya pengaruh yang bermakna dilakukan analisis data menggunakan analisis Varian Satu Arah (Uji F). Bila terdapat perbedaan yang bermakna dilanjutkan dengan Uji BNT (Beda Nyata Terkecil) pada taraf 5\% dan 1\% untuk mengetahui derajat beda antar kelompok perlakuan.

\section{HASIL DAN PEMBAHASAN}

Hasil pengamatan pengaruh pemberian tepung daun sambiloto pada broiler terhadap ratarata konsumsi pakan kumulatif dapat dilihat pada Gambar 1.

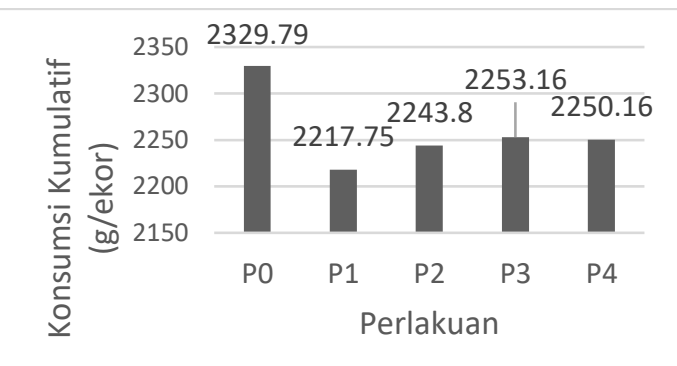

Gambar 1. Diagram rata-rata konsumsi pakan kumulatif (g/ekor) broiler selama pemeliharaan

Hasil sidik ragam rata-rata konsumsi pakan kumulatif broiler dengan pemberian tepung daun sambiloto menunjukkan hasil yang tidak berbeda nyata $(\mathrm{P}>0.05)$. Didukung penelitian yang dilakukan. Muthivanan (2006) menyatakan bahwa penggunaan sambiloto dalam pakan sebagai antibiotik alami tidak berpengaruh terhadap konsumsi pakan broiler. Dosis pemberian tepung daun sambiloto sampai dengan $0,6 \%$ dari jumlah pakan yang diberikan ini mengacu pada penelitian Tipakorn (2002) yang menggunakan dosis sampai dengan $0,4 \%$ dari jumlah pakan yang diberikan. 


\section{Pertambahan bobot badan dan bobot badan akhir}

Hasil pengamatan pengaruh pemberian tepung daun sambiloto terhadap pertambahan bobot badan kumulatif broiler dapat dilihat pada pada Gambar 3. Hasil sidik ragam rata-rata pertambahan bobot badan kumulatif broiler dengan pemberian tepung daun sambiloto menunjukkan hasil yang tidak berbeda nyata $(\mathrm{P}>0,05)$.

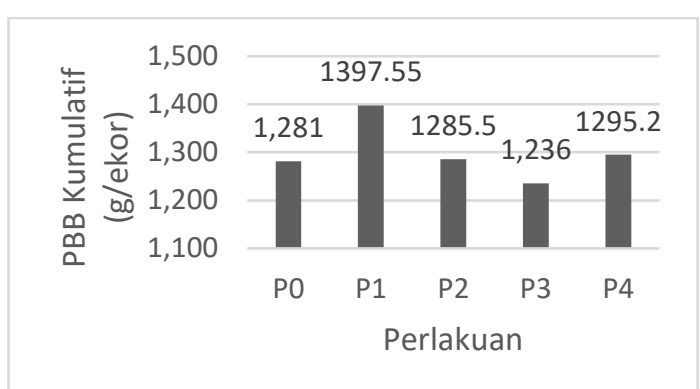

Gambar 2. Diagram rata-rata pertambahan bobot badan kumulatif (g/ekor) broiler

Hasil pengamatan pengaruh pemberian tepung daun sambiloto terhadap bobot badan akhir kumulatif broiler dapat dilihat pada Gambar 3.

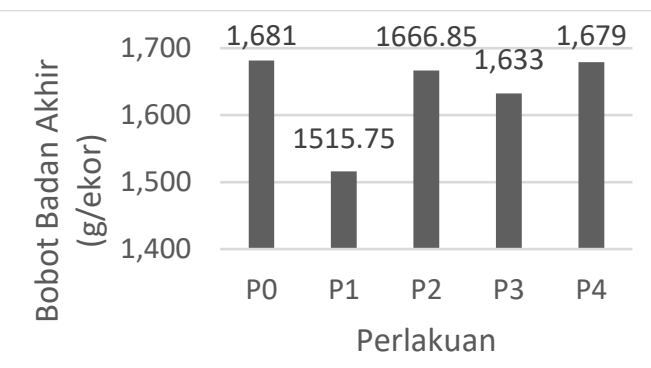

Gambar 3. Diagram rata-rata bobot badan akhir kumulatif (g/ekor) broiler selama pemeliharaan

Hasil sidik ragam rata-rata bobot badan akhir kumulatif broiler dengan pemberian tepung daun sambiloto menunjukkan hasil yang tidak berbeda nyata $(\mathrm{P}>0,05)$. Pemberian tepung daun sambiloto $0,6 \%$ pada broiler yang terinfeksi E. coli $(\mathrm{P} 4)$ dapat menghasilkan bobot badan yang tidak jauh berbeda dengan kontrol (ayam sehat) yaitu 1.679,4 g/ekor (P4) sedangkan bobot badan kontrol 1.681,4 g/ekor.

\section{Konversi pakan}

Hasil pengamatan pengaruh pemberian tepung daun sambiloto terhadap konversi pakan kumulatif broiler dapat dilihat pada Gambar 4.

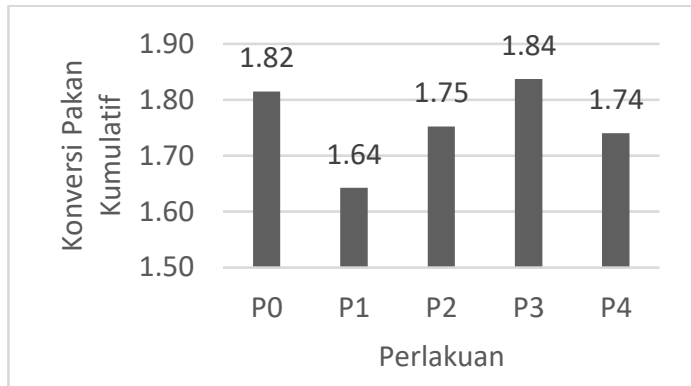

Gambar 4. Diagram rata-rata konversi pakan kumulatif broiler selama pemeliharaan

Hasil sidik ragam rata-rata konversi pakan kumulatif broiler dengan pemberian tepung daun sambiloto menunjukkan hasil yang tidak berbeda nyata $(\mathrm{P}>0,05)$. Tipakorn (2002) menyatakan bahwa, pemberian pakan yang dicampur sambiloto hingga $0,4 \%$ dari jumlah pakan tidak berpengaruh terhadap konversi pakan dan menyatakan bahwa sambiloto merupakan bahan pengganti alternatif bagi chlortetracycline pada broiler.

Konversi pakan perlu diperhatikan karena erat hubungannya dengan biaya produksi karena dengan bertambah besarnya konversi pakan berarti biaya produksi pada setiap satuan bobot badan akan bertambah besar (Yunilas et al., 2005). Konversi pakan P3 pada penelitian ini paling tinggi dibandingkan dengan perlakuan lain yaitu 1,8375 disebabkan karena konsumsinya yang besar sedangkan pertambahan bobot badannya sangat kecil dibanding dengan perlakuan lain.

\section{Efektivitas anti bakteri}

Hasil pengamatan pengaruh pemberian tepung daun sambiloto terhadap efektivitas antibakteri kumulatif pada sampel ekskreta broiler umur 21 hari dan 28 hari dapat dilihat pada Gambar 5 dan Gambar 6.

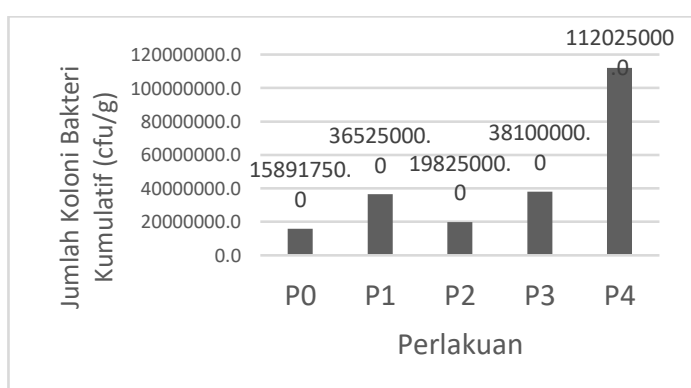

Gambar 5. Diagram jumlah koloni bakteri kumulatif (cfu/g) pada sampel ekskreta broiler umur 21 hari 


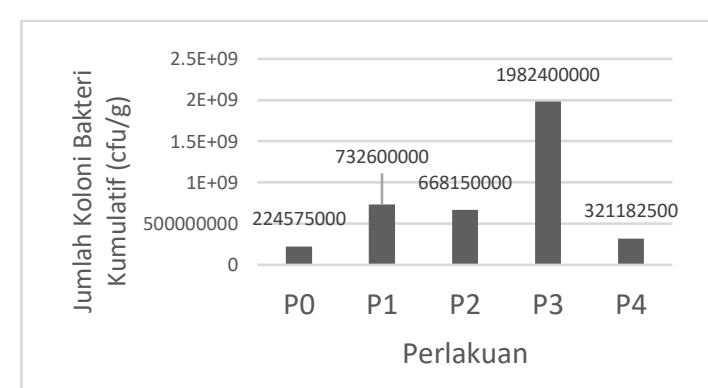

Gambar 6. Diagram jumlah koloni bakteri kumulatif (cfu/g) pada sampel ekskreta broiler umur 28 hari

Widyawati (2007) menyatakan bahwa, sambiloto mempunyai aktivitas antibakteri terhadap S. aureus dan E. coli. Pengujian in vitro tentang penggunaan serbuk daun sambiloto telah dilakukan oleh Rachmawati dan Hamid (2006), yang menyatakan bahwa sambiloto bersifat bakteriostatik terhadap Pseudomonas aeruginos. Efektivitas antibakteri dipengaruhi oleh jumlah dosis yang diberikan serta jumlah sambiloto yang dikonsumsi oleh ayam. Jumlah koloni bakteri yang dihitung pada penelitian ini tidak hanya bakteri E. coli saja tetapi semua koloni bakteri yang tampak pada saat penghitungan dilakukan. Hal ini dikarenakan metode yang digunakan adalah metode Total Plate Count. Hasil penghitungan jumlah bakteri pada penelitan ini yaitu semakin tinggi dosis sambiloto maka jumlah koloni bakteri juga semakin tinggi, tetapi pada penghitungan selisih jumlah bakteri pada umur 28 dan 21 hari terlihat bahwa semakin tinggi dosis tepung daun sambiloto maka selisih jumlah koloni bakteri semakin kecil, kecuali pada P3. Hal ini dapat dilihat pada P1 yang diinfeksi $E$. coli tanpa sambiloto selisih jumlah kenaikan bakteri sebesar $6,96 \times 10^{8} \mathrm{cfu} / \mathrm{g}$, dan untuk P2 dengan pemberian tepung daun sambiloto $0,2 \%$ selisih pertambahan jumlah bakterinya $6,48 \times 10^{8}$ cfu/g, sedangkan pada $\mathrm{P} 4$ dengan pemberian tepung daun sambiloto $0,6 \%$ selisih pertambahan bakterinya hanya $2,09 \times 10^{8} \mathrm{cfu} / \mathrm{g}$. Hasil selisih jumlah bakteri tersebut dapat dikatakan bahwa semakin tinggi pemberian tepung daun sambiloto maka selisih jumlah pertambahan bakteriakan menurun.

\section{SIMPULAN}

Berdasarkan hasil penelitian yang telah dilakukan dapat disimpulkan bahwa pemberian tepung daun sambiloto pada level $0,6 \%$ dalam pakan menunjukkan level yang paling baik untuk menghambat pertambahan jumlah bakteri.

\section{DAFTAR PUSTAKA}

Mathivanan. 2006. Panchagavya and Andrographis paniculata as alternatives to antibiotic growth promoter on broiler production and carcass characteristics. International J. Poultry Sci. 5(12): 11441147.

Mustaqim. 2006. Persentase bobot karkas, organ dalam, dan lemak abdomen broiler yang diberi imbuhan tepung daun sambiloto (Andrographis paniculataNees). J. Ilmu Peternakan 9(16):112-118

Rachmawati dan H. Hamid. 2006. Pengaruh Penggunaan Sambiloto (Andrographis Paniculata Nees) terhadap Kandungan Residu Aflatoksin dalam Hati Itik dan Hubungannya dengan Aflatoksikosis. Seminar Nasional Teknologi Peternakan dan Venteriner. Balai PenelitianVeteriner. Hal. 21-29

Tipakorn, N. 2002. Effects of Andrographispaniculata (Burm. F.) Nees on Performance, Mortality and Coccidiosis in Broiler Chickens. Doctoral Dissertation. George August University. Gottingen. Germany.

Widyawati.2007. Aspek farmakologi sambiloto (Andrographis paniculata Nees). Majalah Kedokteran Nusantara 3(40): 216-217.

Yunilas, E. Mirwandhono, dan O. Sinaga. 2005. Pengaruh pemberiaan tepung temulawak (Curcuma Xanthorrizha Roxb) dalam ransum terhadap kualitas karkas ayam broiler umur 6 minggu. J. Agribisnis Peternakan 2(1): 62-66. 